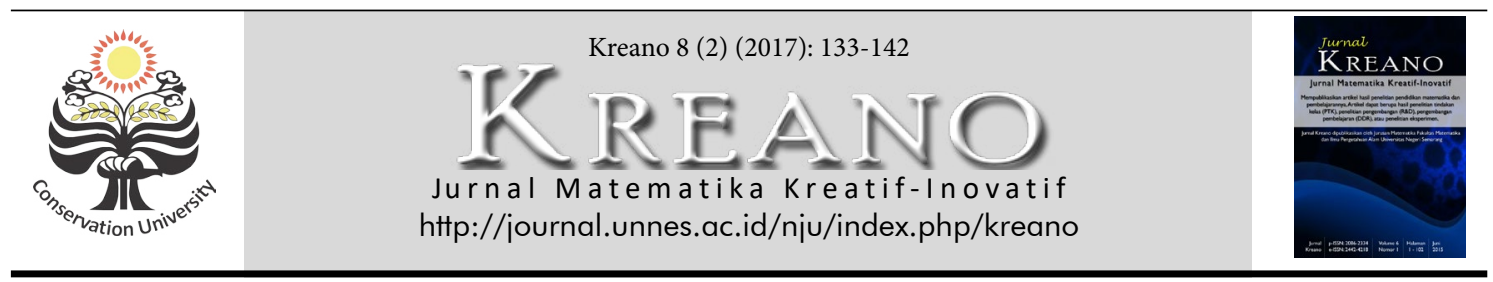

\title{
Aktivitas Metakognitif Siswa SMP dalam Pemecahan Masalah Matematika Berdasarkan Kemampuan Matematika
}

\author{
Aria Joko Pramono ${ }^{1}$ \\ 'Universitas Negeri Surabaya \\ Email: ariajp067@gmail.com
}

DOI: http://dx.doi.org/10.15294/kreano.v8i2.6703

Received : August 2016; Accepted: June 2017; Published: December 2017

\begin{abstract}
Abstrak
Aktivitas metakognitif adalah berkaitan dengan kesadaran dan pengaturan terhadap pengetahuan tentang proses dan hasil pikir dalam kegiatan merencanakan (planning) proses berpikir, memantau (monitoring) proses berpikir, dan mengevaluasi (evaluation) proses dan hasil berpikir. Penelitian ini bertujuan untuk mendeskripsikan aktivitas metakognitif siswa SMP berdasarkan kemampuan matematika tinggi, sedang, dan rendah. Analisis data dilakukan dalam penelitian ini meliputi; reduksi, pemaparan, dan menarik kesimpulan aktivitas metakognitif subjek dalam pemecahan masalah matematika. Berdasarkan analisis data, subjek berkemampuan matematika tinggi dan sedang dalam pemecahan masalah, melakukan kegiatan perencanaan proses berpikirnya, memantau proses berpikirnya, dan mengevaluasi proses dan hasil berpikirnya dalam setiap tahap pemecahan masalah (memahami masalah, menyusun rencana penyelesaian, melaksanakan rencana penyelesaian, dan memeriksa kembali). Sedangkan subjek berkemampuan matematika rendah dalam pemecahan masalah, melakukan kegiatan perencanaan proses berpikirnya, memantau proses berpikirnya, dan mengevaluasi proses dan hasil berpikirnya dalam tahap memahami masalah, dan tahap melaksanakan rencana penyelesaian. Sedangkan pada tahap menyusun rencana penyelesaian subjek berkemampuan matematika rendah melakukan kegiatan perencanaan proses berpikirnya, dan memantau proses berpikirnya. Dan dalam tahap memeriksa kembali subjek berkemampuan matematika rendah hanya melakukan kegiatan mengevaluasi.
\end{abstract}

\begin{abstract}
Activity of metacognitive has relation with awareness and control on knowledge about process and result of thinking in activity of planning thinking process, monitoring process of thinking, and evaluating process and result of thinking. This research aims to describe metacognitive activity of the junior high school students based on high, medium, and low mathematics skills. Data analysis used in this research consists of reduction, discussion, and conclusion in term of metacognitive activities of the subject in mathematics problem solving. Based on data analysis, subject with high and medium mathematics skills in problem solving, conduct activity of thinking process planning, monitoring thinking process, and evaluating process and result of thinking in each problem solving stages (comprehending the problem, structuring problem solving plan, conducting problem solving plan, and rechecking). Subject with low mathematics skills in problem solving, conducting activity of thinking process plan, monitoring thinking process, and evaluating process and result of thinking in each problem solving stages, and stage of conducting problem solving plan. On stage of structuring problem solving plan subject with low mathematics skills conducts activity of thinking process plan, and monitors thinking process. On stage of rechecking subject with low mathematics skills only conducts activity of evaluation.
\end{abstract}

Keywords: activity of metacognitive; mathematics problem solving; mathematics skills 


\section{PENDAHULUAN}

Di era globalisasi, perkembangan ilmu pengetahuan dan teknologi dari waktu ke waktu semakin pesat. Hal ini mengakibatkan adanya persaingan dalam berbagai bidang kehidupan karena dibutuhkannya sumber daya manusia (SDM) yang berkualitas, bernalar tinggi, dan memiliki kemampuan memproses informasi. Peningkatan kualitas SDM dapat diwujudkan melalui peningkatan kualitas pendidikan. Pendidikan merupakan salah satu sektor yang cukup strategis dalam membentuk dan mengelola sumber daya manusia yang berkualitas dalam arti manusia yang memiliki wawasan yang luas dalam bidang ilmu pengetahuan dan teknologi. Pendidikan mempunyai fungsi yang esensial dalam mempersiapkan sumber daya manusia yang nantinya akan menjadi penggerak pembangunan di segala segi kehidupan.

Pendidikan matematika sebagai salah satu aspek pendidikan memiliki peran penting dalam peningkatan mutu pendidikan khususnya di dalam menghasilkan sumber daya manusia yang berkualitas. Matematika adalah mata pelajaran yang diajarkan di sekolah mulai dari tingkat Sekolah Dasar hingga Sekolah Menengah Atas, yang selanjutnya dikatakan sebagai matematika sekolah. Matematika sekolah adalah unsur-unsur atau bagian-bagian dari matematika yang dipilih berdasarkan atau berorientasi kepada kepentingan pendidikan dan kepentingan untuk menguasai dan memanfaatkan teknologi di masa depan (Soedjadi, 2000).

Pembelajaran matematika di sekolah memiliki empat tujuan utama yaitu : (1) melatih cara berpikir dan bernalar dalam menarik kesimpulan, (2) mengembangkan aktivitas kreatif yang melibatkan imajinasi, intuisi, dan penemuan dengan mengembangkan pemikiran divergen, originil, rasa ingin tahu, prediksi dan dugaan serta mencoba-coba, (3) mengembangkan kemampuan pemecahan masalah dan (4) mengembangkan kemampuan menyampaikan informasi dan mengkomunikasikan gagasan (Depdiknas, 2006). Berdasarkan tujuan pembelajaran matematika di sekolah, pemecahan masalah merupakan salah satu fokus tujuan. Hal ini sejalan dengan yang direkomendasi National Council of Teachers of
Mathematics (NCTM), bahwa fokus pembelajaran matematika sekolah adalah pemecahan masalah. Pendekatan pemecahan masalah dilaksanakan untuk memberikan bekal yang cukup kepada siswa agar memiliki kemampuan untuk memecahkan masalah. Selain itu juga akan berguna untuk memperoleh pengetahuan dan membentuk cara berpikir serta dapat bersikap dalam memecahkan masalah yang dihadapi dalam kehidupan sehari-hari (NCTM, 1980).

Untuk memperoleh hasil dan manfaat yang optimal dalam pemecahan masalah matematika, harus dilakukan melalui langkah-langkah pemecahan yang terorganisasi dengan baik. Salah satu bentuk pengorganisasian pemecahan masalah matematika adalah seperti yang dikemukakan oleh Polya (1973) yang meliputi 4 langkah, yakni: (1) memahami masalah; (2) menyusun rencana penyelesaian; (3) melaksanakan rencana penyelesaian; (4) memeriksa kembali jawaban. Melalui langkah-langkah yang dikemukan oleh Polya tersebut memungkinkan terlaksananya pemecahan masalah yang benar, sistematis, serta terbentuknya pola pikir yang tersruktur dengan baik pada diri seseorang pada saat menghadapi masalah yang harus dipecahkan.

Johnson \& Rising (1972) menyatakan bahwa pemecahan masalah matematika merupakan proses mental yang kompleks yang memerlukan visualisasi, imajinasi, manipulasi, analisis, abstraksi dan penyatuan ide. Untuk melakukan hal tersebut siswa perlu mengelola pemikirannya dengan baik, dengan memanfaatkan pengetahuan yang sudah dimiliki, mengontrol dan merefleksi proses dan hasil pemikirannya sendiri, apa yang dipikirkannya yang dapat membantu dalam menyelesaikan masalah. Hal tersebut sejalan dengan pendapat Gartmann \& Freiberg (1995) bahwa memberikan kesempatan kepada siswa untuk memecahkan masalah akan membantu mereka menjadi sadar akan proses berpikir mereka dalam memecahkan masalah.

Menurut Mennun \& Hart (2012) ketika individu menyadari tentang pengetahuannya dan memiliki kemampuan untuk mengendalikan kemampuan tersebut dalam proses pemecahan masalah serta mampu mengatur pi- 
kirnya dalam pengambilan keputusan dikenal sebagai aktivitas metakognitif.

Menurut Flavell (1979), metakognisi diartikan sebagai "kognisi tentang kognisi" atau "berpikir tentang berpikir." Untuk hal yang sama, Lee dan Baylor (2006) menyebutkan bahwa metakognisi adalah kesadaran terhadap aktivitas kognisi; dalam hal ini, metakognisi berkaitan dengan bagaimana seseorang menyadari proses berpikirnya. Sedangkan menurut O'Neil dan Brown (1997) metakognisi sebagai proses seseorang berpikir tentang sesuatu yang dipikirkannya dalam rangka membangun strategi untuk memecahkan masalah. Secara umum berdasarkan pendapat di atas maka metakognisi merupakan kesadaran seseorang terhadap proses berpikirnya sendiri untuk membangun strategi yang tepat dalam memecahkan masalah.

Menurut Bruning, Schraw \& Ronning (1995) metakognisi secara umum berkaitan dengan dua dimensi berpikir, yaitu: (1) selfawareness of cognition, yaitu kesadaran yang dimiliki seseorang tentang berpikirnya; (2) self-regilation of cognition, yaitu kemampuan seseorang menggunakan kesadaranya untuk mengatur proses berpikirnya. Sedangkan Woolfolk (2009) menjelaskan bahwa metakognisi merujuk kepada cara untuk meningkatkan kesadaran mengenai proses berpikir dan belajar yang dilakukan. Kesadaran ini akan terwujud apabila seseorang dapat mengawali berpikirnya dengan merencanakan (planning), memantau (monitoring) dan mengevaluasi (evaluating) hasil dan aktivitas kognitifnya.

Berkaitan dengan maksud di atas, maka penulis memandang perlu untuk mengetahui aktivitas metakognitif yang dilakukan siswa SMP dalam pemecahkan masalah matematika yang ditinjau dari kemampuan matematika. Mengingat siswa SMP berada pada usia 11 tahun ke atas (11-15 tahun). Berdasarkan usia perkembangan dari Teori Piaget (dalam Wadsworth, 1984), pada usia ini kemampuan berpikir siswa sudah termasuk pada tahap operasional formal.

Adapun tujuan penelitian ini adalah untuk: (1) Mendeskripsikan aktivitas metakognitif siswa SMP dalam pemecahan masalah matematika berdasarkan kemampuan mate- matika rendah; (2) Mendeskripsikan aktivitas metakognitif siswa SMP dalam pemecahan masalah matematika berdasarkan kemampuan matematika sedang; (3) Mendeskripsikan aktivitas metakognitif siswa SMP dalam pemecahan masalah matematika berdasarkan kemampuan matematika tinggi.

\section{METODE}

Penelitian ini bermaksud untuk menggali dan mendeskripsikan aktivitas metakognitif siswa dalam pemecahan masalah matematika, oleh karena itu penelitian ini didesain dengan jenis penelitian eksploratif dengan pendekatan deskriptif kualitatif. Dikatakan sebagai penelitian eksploratif karena peneliti ingin menggali secara mendalam tentang metakognisi subjek yang merujuk pada hal-hal yang berkaitan dengan aktivitas metakognitif subjek, sedangkan pendekatan kualitatif merupakan prosedur penelitian yang menghasilkan data deskriptif berupa kata-kata tertulis atau lisan dari orang-orang dan perilaku yang dapat diamati.

Pengumpulan data dalam penelitian ini dilakukan dengan 2 teknik yaitu tes dan wawancara. Proses pengumpulan data tes diperoleh dari TKM dan TPM. TKM digunakan untuk pemilihan subjek penelitian sedangkan TPM digunakan untuk mendeskripsikan atau mengetahui aktivitas metakognitif siswa dalam pemecahan masalah matematika. Sedangkan wawancara digunakan untuk menggali informasi yang mendalam mengenai aktivitas metakognitif siswa dalam pemecahan masalah matematika. Wawancara dilakukan setelah subjek penelitian menyelesaikan TPM.

Secara garis besar prosedur penelitian yang digunakan oleh penelitian terdiri dari empat, yaitu:

\section{Tahap Persiapan}

Pada tahap ini kegiatan yang dilakukan adalah: (a) Menyampaikan surat izin permohonan untuk melakukan penelitian; (b) Merancang instrumen penelitian yang meliputi soal TKM, TPM dan pedoman wawancara; (c) Mengkonsultasikan instrumen penelitian dengan pembimbing I dan pembimbing $\mathrm{II}_{i}$ (d) Melaksanakan validasi instrumen penelitian 
(soal TKM dan TPM), sehingga didapatkan instrumen yang valid. Instrumen penelitian yang divalidasi dan disetujui oleh validator digunakan dalam penelitian. Lembar validasi digunakan untuk mengumpulkan data tentang pendapat, saran dan komentar para ahli mengenai instrumen penelitian yang dibuat. Instrumen dikatakan valid apabila kesimpulan pada lembar validasi adalah layak digunakan atau layak digunakan dengan perbaikan.

\section{Tahap Pelaksanaan}

Pada tahap ini kegiatan yang dilakukan adalah: (a) Melakukan tes pengelompokan tingkat kemampuan matematika siswa untuk menentukan subjek penelitian; (b) Memberikan TPM kepada subjek penelitian. Selanjutnya subjek mengerjakan soal sambil diwawancarai agar peneliti mengetahui proses pemecahan masalah yang dilakukan oleh subjek.

\section{Tahap Penyelesaian}

Pada tahap ini kegiatan yang dilakukan adalah: (a) Mengelola dan menganalisis data hasil penelitian untuk mendapatkan aktivitas metakognitif dalam pemecahan masalah matematika; (b) Menyusun kerangka dan isi laporan, penulisan laporan dan penelahan hasil penelitian.

\section{HASIL DAN PEMBAHASAN}

\section{Aktivitas Metakognitif Siswa Berke- mampuan Matematika Tinggi dalam Pemecahan Masalah Matematika}

Berdasarkan analisis data penelitian menunjukkan bahwa siswa berkemampuan matematika tinggi melakukan aktivitas metakognitif (perencanaan, mamantau dan evaluasi) dalam tiap tahap pemecahan masalah (memahami masalah, menyusun rencana penyelesaian, melaksanakan rencana penyelesaian, dan memeriksa kembali). Berikut ini simpulan aktivitas metakognitif siswa berkemampuan matematika tinggi dalam pemecahan masalah:

Pada tahap memahami masalah siswa berkemampuan matematika tinggi melakukan: (a) Aktivitas perencanaan saat memikirkan cara memahami masalah, yaitu dengan cara membaca masalah tanpa suara (dalam hati) sambil membuat garis di masalah; (b) Aktivitas memantau saat mengecek pemahaman terhadap masalah, yaitu dengan cara mengungkapkan apa yang dipahami pada masalah; dan saat adanya hal lain yang dipahami pada masalah, yaitu dengan cara memperhatikan kembali masalah; (c) Aktivitas evaluasi saat memeriksa pemahaman terhadap masalah yaitu dengan cara memperhatikan kembali masalah; dan saat memeriksa kesesuaian yang diungkapkan dari yang dipahami pada masalah yaitu, dengan cara memperhatikan kembali masalah.

Pada tahap menyusun rencana penyelesaian siswa berkemampuan matematika tinggi melakukan: (a) Aktivitas perencanaan saat mamikirkan alur rencana pemecahan masalah, yaitu memikirkan mencari panjang sisisisi persegi, kemudian memikirkan rumus dan teorema yang akan digunakan untuk pemecahan masalah; dan saat mamikirkan waktu yang akan digunakan untuk pemecahan masalah; (b) Aktivitas memantau saat mengecek adanya rumus dan teorema yang akan digunakan untuk penyelesain masalah, yaitu dengan cara mengungkapkan rumus dan teorema yang akan digunakan; dan saat adanya rumus dan teorema yang akan gunakan selain yang diungkapkan, yaitu dengan cara memperhatikan kembali masalah; (c) Aktivitas evaluasi saat memeriksa kesesuaian alur rencana penyelesaian masalah, yaitu dengan cara memperhatikan kembali masalah; saat memeriksa kecocokan rumus dan teorema yang akan digunakan untuk penyelesain masalah, yaitu dilakukan cara memperhatikan kembali masalah; dan saat memeriksa kesesuaian waktu yang akan digunakan untuk penyelesain masalah, yaitu dengan cara memperhatikan kembali masalah.

Pada tahap melaksanakan rencana penyelesaian siswa berkemampuan matematika tinggi melakukan: (a) Aktivitas perencanaan saat memikirkan penggunaan konsep-konsep perkalian, pembagian, penjumlah, pengurangan, pengakaran, dan teorema Pythagoras sebagai pengetahuan prasyarat untuk menentukan panjang sisi persegi, panjang sisi persegi dan panjang sisi persegi ; saat mamikirkan dan menuliskan apa yang diketa- 
hui dan yang ditanyakan pada masalah; saat memikirkan membuat gambar; dan saat memikirkan pelaksanaan rencana penyelesaian masalah, yaitu dengan menentukan panjang sisi persegi, menentukan panjang sisi persegi, menetukan panjang sisi persegi, menentukan panjang sisi persegi, dan menentukan luas daerah yang diarsir; (b) Aktivitas memantau saat mengecek kecermatan perhitungan pelaksanaan rencana penyelesaian masalah, yaitu dengan memperhatikan kembali perhitungan pada saat menentukan panjang sisi persegi, memperhatikan kembali perhitungan pada saat menentukan panjang sisi persegi, memperhatikan kembali perhitungan pada saat menentukan panjang sisi persegi , memperhatikan kembali perhitungan pada saat menentukan panjang sisi persegi, dan memperhatikan kembali perhitungan pada saat menentukan luas daerah yang diarsir; (c) Aktivitas evaluasi saat memeriksa kesesuaian apa yang diketahui dan yang ditanyakan pada masalah, yaitu dengan cara memperhatikan kembali masalah; saat memeriksa kesesuaian gambar, yaitu dilakukan dengan cara memperhatikan kembali masalah; dan saat memeriksa kesesuaian pelaksanaan rencana penyelesaian masalah, yaitu memperhatikan kembali apa yang dilakukan saat menentukan panjang sisi persegi, memperhatikan kembali apa yang dilakukan saat menentukan panjang sisi persegi, memperhatikan kembali apa yang dilakukan saat menentukan panjang sisi persegi , memperhatikan kembali apa yang dilakukan saat menentukan panjang sisi persegi, dan memperhatikan kembali apa yang dilakukan saat menentukan luas daerah yang diarsir.

Pada tahap memeriksa kembali siswa berkemampuan matematika tinggi melakukan: (a) Aktivitas perencanaan saat memikirkan apa saja yang perlu diperiksa, yaitu memeriksa penggunaan teorema Pythagoras dan penjumlahan, perkalian, pembagian, serta pengakaran dari hasil perhitungan; (b) Aktivitas memantau saat mengecek kebenaran pemeriksa kembali masalah, yaitu dilakukan dengan cara mengecek kembali penggunaan teorema Pythagoras dan perhitungan; (c) Aktivitas evaluasi saat yakin bahwa langkahlangkah yang digunakan sudah tepat dan benar, yaitu dilakukan dengan cara memperhatikan kembali penyelesaian masalah yang sudah dikerjakan; saat mengevaluasi pencapaian tujuan, yaitu dilakukan dengan cara memperhatikan masalah dan hasil pekerjaan yang sudah dikerjakan; dan saat memperhatikan kekuatan atau kelemahan diri sendiri dalam penyelesaian masalah.

\section{Aktivitas Metakognitif Siswa Berke- mampuan Matematika Sedang dalam Pemecahan Masalah Matema- tika}

Berdasarkan analisis data penelitian menunjukkan bahwa siswa berkemampuan matematika sedang melakukan aktivitas metakognitif (perencanaan, mamantau dan evaluasi) dalam tiap tahap pemecahan masalah (memahami masalah, menyusun rencana penyelesaian, melaksanakan rencana penyelesaian, dan memeriksa kembali). Berikut ini simpulan aktivitas metakognitif siswa berkemampuan matematika sedang dalam pemecahan masalah:

Pada tahap memahami masalah siswa berkemampuan matematika sedang melakukan: (a) Aktivitas perencanaan saat memikirkan cara mamahami masalah yaitu dengan cara membaca masalah beberapa kali sampai masalah dapat dipahami; (b) Aktivitas memantau saat mengecek pemahaman terhadap masalah yaitu dengan cara mengungkapkan apa yang dipahami pada masalah; dan saat adanya hal lain yang dipahami pada masalah yaitu dengan cara memperhatikan kembali masalah; (c) Aktivitas evaluasi saat memeriksa pemahaman terhadap masalah yaitu dengan cara memperhatikan kembali masalah; dan saat memeriksa kesesuaian yang diungkapkan dari yang dipahami pada masalah yaitu dengan cara memperhatikan kembali masalah.

Pada tahap menyusun rencana penyelesaian siswa berkemampuan matematika sedang melakukan: (a) Aktivitas perencanaan saat memikirkan alur rencana pemecahan masalah, yaitu dengan memikirkan untuk mencari panjang sisi persegi, panjang sisi persegi , , dan serta luas daerah yang diarsir; dan saat memperkirakan waktu yang akan di- 
gunakan untuk pemecahan; (b) Aktivitas memantau saat mengecek adanya rumus yang akan digunakan untuk penyelesain masalah, yaitu dengan mengungkapkan adanya rumus luas persegi yang akan digunakan untuk mencari panjang sisi persegi, seperti mencari sisi miring pada segitiga yang akan digunakan untuk mencari panjang sisi persegi , , dan serta rumus luas persegi dan persegi yang akan digunakan untuk mencari luas daerah yang diarsir; (c) Aktivitas evaluasi saat memeriksa kebenaran rencana yang akan digunakan dalam pemecahan masalah, yaitu dengan memeriksa kesesuaian rencana untuk mencari panjang sisi persegi , panjang sisi persegi , , dan serta mencari luas daerah yang diarsir; saat memeriksa kesesuaian alur pemacahan masalah yang digunakan untuk pemecahan masalah, yaitu dilakukan cara memperhatikan kembali masalah; dan saat memeriksa kesesuaian waktu yang akan digunakan untuk penyelesain masalah, yaitu dengan cara memperhatikan kembali masalah.

Pada tahap melaksanakan rencana penyelesaian siswa berkemampuan matematika sedang melakukan: (a) Aktivitas perencanaan saat menggunakan konsep-konsep prasyarat perkalian, pembagian, penjumlah, pengurangan, pengakaran, dan pengetahuan prasyarat untuk menentukan panjang sisi persegi, panjang sisi persegi dan panjang sisi persegi ; saat mamikirkan dan menuliskan apa yang diketahui dan yang ditanyakan pada masalah; dan saat memikirkan pelaksanaan rencana penyelesaian masalah, yaitu dengan menentukan panjang sisi persegi, menentukan panjang sisi persegi , menetukan panjang sisi persegi , menentukan panjang sisi persegi, dan menentukan luas daerah yang diarsir; (b) Aktivitas memantau saat mengecek kecermatan perhitungan pelaksanaan rencana penyelesaian masalah, yaitu dengan memperhatikan kembali perhitungan pada saat menentukan panjang sisi persegi, memperhatikan kembali perhitungan pada saat menentukan panjang sisi persegi, memperhatikan kembali perhitungan pada saat menentukan panjang sisi persegi, memperhatikan kembali perhitungan pada saat menentukan panjang sisi persegi , dan memperhatikan kembali perhitungan pada saat menentukan luas daerah yang diar- sir; (c) Aktivitas evaluasi saat memeriksa kesesuaian kesesuaian apa yang diketahui dan yang ditanyakan pada masalah, yaitu dengan cara memperhatikan kembali masalah; dan saat memeriksa kesesuaian pelaksanaan rencana penyelesaian masalah, yaitu memperhatikan kembali apa yang dilakukan saat menentukan panjang sisi persegi, memperhatikan kembali apa yang dilakukan saat menentukan panjang sisi persegi , memperhatikan kembali apa yang dilakukan saat menentukan panjang sisi persegi, memperhatikan kembali apa yang dilakukan saat menentukan panjang sisi persegi , dan memperhatikan kembali apa yang dilakukan saat menentukan luas daerah yang diarsir.

Pada tahap memeriksa kembali siswa berkemampuan matematika sedang melakukan: (a) Aktivitas perencanaan saat memikirkan apa saja yang perlu diperiksa, yaitu dilakukan dengan memeriksa dari awal sampai akhir pemecahan masalah; (b) Aktivitas memantau saat mengecek kebenaran pemeriksa kembali masalah, yaitu dilakukan dengan cara mengecek kembali pemeriksaan yang telah dilakukan; (c) Aktivitas evaluasi saat meyakinkan pada diri sendiri bahwa langkah-langkah yang digunakan sudah tepat, yaitu dilakukan dengan cara memperhatikan kembali penyelesaian masalah yang sudah dikerjakan; saat mengevaluasi pencapaian tujuan, yaitu dilakukan dengan cara memperhatikan masalah dan hasil pekerjaan yang sudah dikerjakan; dan saat memperhatikan kekuatan atau kelemahan diri sendiri dalam penyelesaian masalah.

\section{Aktivitas Metakognitif Siswa Berke- mampuan Matematika Rendah dalam Pemecahan Masalah Matema- tika}

Berdasarkan analisis data penelitian menunjukkan bahwa siswa berkemampuan matematika rendah tidak lengkap melakukan aktivitas metakognitif (perencanaan, mamantau dan evaluasi) dalam tiap tahap pemecahan masalah (memahami masalah, menyusun rencana penyelesaian, melaksanakan rencana penyelesaian, dan memeriksa kembali). Berikut ini simpulan aktivitas metakognitif siswa 
berkemampuan matematika rendah dalam pemecahan masalah:

Pada tahap memahami masalah siswa berkemampuan matematika rendah melakukan: (a) Aktivitas perencanaan saat memikirkan cara mamahami masalah yaitu dengan cara membaca masalah sambil memahami sampai beberapa kali, sampai masalah dapat dipahami; (b) Aktivitas memantau saat mengecek pemahaman terhadap masalah yaitu dengan cara mengungkapkan apa yang dipahami pada masalah; (c) Aktivitas evaluasi saat memeriksa pemahaman terhadap masalah yaitu dengan cara memperhatikan kembali masalah; dan saat memeriksa kesesuaian yang diungkapkan dari yang dipahami pada masalah yaitu dengan cara memperhatikan kembali masalah.

Pada tahap menyusun rencana penyelesaian siswa berkemampuan matematika rendah melakukan: (a) Aktivitas perencanaan saat mamikirkan alur rencana pemecahan masalah, yaitu dengan memikirkan untuk mencari panjang sisi persegi , , , dan , kurang yakin akan rencana untuk mencari panjang sisi persegi, , dan seperti mencari sisi miring pada segitiga serta memikirkan alur rencana pemecahan untuk mencari luas daerah yang diarsir; dan saat memikirkan bermanfaat dari data yang diketahui; (b) Aktivitas memantau saat mengecek adanya rumus yang akan digunakan untuk penyelesain masalah, yaitu dengan mengungkapkan adanya rumus luas persegi yang akan digunakan untuk mencari panjang sisi persegi, penggunaan mencari sisi miring pada segitiga yang akan digunakan untuk mencari panjang sisi persegi, , dan, serta adanya rumus luas persegi dan persegi yang akan digunakan untuk mencari luas daerah yang diarsir; dan menyadari kemampuan dirinya dengan merasa kesulitan karena lupa akan pengetahuan prasyarat.

Pada tahap melaksanakan rencana penyelesaian siswa berkemampuan matematika rendah melakukan: (a) Aktivitas perencanaan saat menggunakan konsep-konsep prasyarat perkalian, pembagian, penjumlah, pengurangan, pengakaran, dan pengetahuan prasyarat untuk menentukan panjang sisi persegi, panjang sisi persegi dan panjang sisi persegi ; dan saat memikirkan pelaksanaan renca- na penyelesaian masalah, yaitu dengan menentukan panjang sisi persegi, menentukan panjang sisi persegi, menetukan panjang sisi persegi, menentukan panjang sisi persegi, dan menentukan luas daerah yang diarsir; (b) Aktivitas memantau saat mengecek kecermatan perhitungan pelaksanaan rencana penyelesaian masalah, yaitu dengan memperhatikan kembali perhitungan pada saat menentukan panjang sisi persegi ; saat menemukan adanya kesalahan dan melakukan perbaikan pada saat menentukan panjang sisi persegi ; dan saat mengecek kesalahan ketika menghitung pelaksanaan rencana pemecahan masalah, yaitu saat menghitung panjang sisi persegi, menghitung panjang sisi persegi , dan menghitung luas daerah yang diarsir; (c) Aktivitas evaluasi saat memeriksa kesesuaian pelaksanaan rencana penyelesaian masalah, yaitu memperhatikan kembali apa yang dilakukan saat menentukan panjang sisi persegi , memperhatikan kembali apa yang dilakukan saat menentukan panjang sisi persegi, memperhatikan kembali apa yang dilakukan saat menentukan panjang sisi persegi , memperhatikan kembali apa yang dilakukan saat menentukan panjang sisi persegi, dan memperhatikan kembali apa yang dilakukan saat menentukan luas daerah yang diarsir.

Pada tahap memeriksa kembali siswa berkemampuan matematika rendah melakukan aktivitas evaluasi saat yakin bahwa langkah-langkah yang digunakan sudah benar.

Pada pembahasan di atas aktivitas metakognitif siswa berkemampuan matematika tinggi, sedang, dan rendah terlihat bahwa siswa berkemampuan matematika tinggi membuat representasi dari masalah yang diberikan untuk mempermudah memahami masalah, setelah memahami masalah dengan baik siswa berkemampuan matematika tinggi memikirkan suatu strategi dan rencana untuk menyelesaikan masalah, selanjutnya melakukan perhitungan-perhitungan yang diperlukan, kemudian siswa berkemampuan matematika tinggi menginterprestasikan hasil dan menyimpulkan suatu jawaban, untuk meyakinkan bahwa jawaban yang diperoleh sudah tepat dan benar siswa berkemampuan matematika tinggi mengevaluasi pekerjaannya. Hal yang sama dilakukan juga oleh 
siswa berkemampuan matematika sedang dalam menyelesaikan masalah. Sedangkan siswa berkemampuan matematika rendah dalam menyelesaikan masalah sering tidak yakin dengan yang dia kerjakan serta tidak mengevaluasi pekerjaannya. Dengan demikian dapat dikatakan bahwa siswa kemampuan matematika tinggi dan sedang menggunakan strategi metakognisi dalam menyelesaikan masalah yang diberikan. Hal ini sejalan dengan pendapat yang dikemukakan oleh De Corte (2003) bahwa strategi metakognisi yang dapat diterapkan untuk memecahkan masalah matematika terdiri atas 5 tahap yaitu: (1) membangun representasi mental dari suatu masalah, (2) menentukan bagaimana pemecahan masalah tersebut, (3) melakukan perhitungan yang diperlukan, (4) menginterpretasikan hasil dan memformulasikan jawaban, dan (5) mengevaluasi hasil yang dikerjakan. Sedangkan siswa berkemampuan matematika rendah tidak lengkap dalam menggunakan strategi metakognisi dalam pemecahan masalah matematika.

\section{PENUTUP}

\section{Kesimpulan}

Aktivitas Metakognitif Siswa Berkemampuan Matematika Tinggi dalam Pemecahan Masalah Matematika

Dari hasil penelitian menunjukkan bahwa aktivitas metakognitif siswa berkemampuan matematika tinggi dalam pemecahan masalah matematika adalah memikirkan cara mamahami masalah; mengecek pemahaman terhadap masalah; mengecek adanya hal lain yang dipahami pada masalah; memeriksa pemahaman terhadap masalah; memeriksa kesesuaian yang diungkapkan dari yang dipahami pada masalah; memikirkan alur rencana pemecahan masalah; mamikirkan waktu yang akan digunakan untuk pemecahan masalah; mengecek adanya rumus dan teorema yang akan digunakan untuk penyelesain masalah; mengecek adanya rumus dan teorema yang akan gunakan selain yang diungkapkan; memeriksa kesesuaian alur rencana penyelesaian masalah; memeriksa kecocokan rumus dan teorema yang akan digunakan untuk penyelesain masalah; memeriksa kesesuaian waktu yang akan digunakan untuk penyelesain masalah; memikirkan penggunaan konsep-konsep perkalian, pembagian, penjumlah, pengurangan, pengakaran, dan teorema Pythagoras sebagai pengetahuan prasyarat; mamikirkan dan menuliskan apa yang diketahui dan yang ditanyakan pada masalah; memikirkan membuat gambar; memikirkan pelaksanaan rencana penyelesaian masalah; mengecek kecermatan perhitungan pelaksanaan rencana penyelesaian masalah; memeriksa kesesuaian apa yang diketahui dan yang ditanyakan pada masalah; memeriksa kesesuaian pelaksanaan rencana penyelesaian masalah; memikirkan apa saja yang perlu diperiksa; mengecek kebenaran pemeriksa kembali masalah; yakin bahwa langkah-langkah yang digunakan sudah tepat dan benar; mengevaluasi pencapaian tujuan; dan memperhatikan kekuatan atau kelemahan diri sendiri dalam penyelesaian masalah.

\section{Aktivitas Metakognitif Siswa Berkemampuan Sedang dalam Pemecahan Masalah Matema- tika}

Dari hasil penelitian menunjukkan bahwa aktivitas metakognitif siswa berkemampuan matematika sedang dalam pemecahan masalah matematika adalah memikirkan cara mamahami masalah; mengecek pemahaman terhadap masalah; mengecek adanya hal lain yang dipahami pada masalah; memeriksa pemahaman terhadap masalah; memeriksa kesesuaian yang diungkapkan dari yang dipahami pada masalah; memikirkan alur rencana pemecahan masalah; memperkirakan waktu yang akan digunakan untuk pemecahan; mengecek adanya rumus yang akan digunakan untuk penyelesain masalah; memeriksa kebenaran rencana yang akan digunakan dalam pemecahan masalah; memeriksa kesesuaian alur pemacahan masalah yang digunakan untuk pemecahan masalah; memeriksa kesesuaian waktu yang akan digunakan untuk penyelesain masalah; menggunakan konsep-konsep prasyarat perkalian, pembagian, penjumlah, pengurangan, pengakaran, dan pengetahuan prasyarat; mamikirkan dan menuliskan apa yang diketahui dan yang ditany- 
akan pada masalah; memikirkan pelaksanaan rencana penyelesaian masalah; mengecek kecermatan perhitungan pelaksanaan rencana penyelesaian masalah; memeriksa kesesuaian kesesuaian apa yang diketahui dan yang ditanyakan pada masalah; memeriksa kesesuaian pelaksanaan rencana penyelesaian masalah; memikirkan apa saja yang perlu diperiksa; mengecek kebenaran pemeriksa kembali masalah; meyakinkan pada diri sendiri bahwa langkah-langkah yang digunakan sudah tepat; mengevaluasi pencapaian tujuan; dan memperhatikan kekuatan atau kelemahan diri sendiri dalam penyelesaian masalah.

\section{Aktivitas Metakognitif Siswa Berkemampuan Rendah dalam Pemecahan Masalah Matema- tika}

Dari hasil penelitian menunjukkan bahwa aktivitas metakognitif siswa berkemampuan matematika rendah dalam pemecahan masalah matematika adalah memikirkan cara mamahami masalah; mengecek pemahaman terhadap masalah; memeriksa pemahaman terhadap masalah; memeriksa kesesuaian yang diungkapkan dari yang dipahami pada masalah; mamikirkan alur rencana pemecahan masalah; memikirkan bermanfaat dari data yang diketahui; mengecek adanya rumus yang akan digunakan untuk penyelesain masalah; menyadari kemampuan dirinya dengan merasa kesulitan karena lupa akan pengetahuan prasyarat; menggunakan konsep-konsep prasyarat perkalian, pembagian, penjumlah, pengurangan, pengakaran, dan pengetahuan prasyarat; memikirkan pelaksanaan rencana penyelesaian masalah; mengecek kecermatan perhitungan pelaksanaan rencana penyelesaian masalah; menemukan adanya kesalahan dan melakukan perbaikan; mengecek kesalahan ketika menghitung pelaksanaan rencana pemecahan masalah; memeriksa kesesuaian pelaksanaan rencana penyelesaian masalah; dan yakin bahwa langkah-langkah yang digunakan sudah benar.

\section{Saran}

Dalam pembelajaran matematika, pada setiap pemecahan masalah, sebaiknya siswa diberikan pertanyaan-pertanyaan yang merangsang siswa untuk berpikir dengan melibatkan aktivitas metakognitifnya. Strategi metakognisi tidak perlu diajarkan sendiri, tetapi dapat diajarkan bersamaan dengan pemecahan masalah. Dalam mengajarkan pemecahan masalah, pemahaman kosep sangat diperlukan, kemudian dilanjutkan dengan latihan-latihan pemecahan masalah.

Siswa perlu dibiasakan memecahkan masalah dengan mengikuti 4 langkah Polya, karena dapat mengembangkan kemampuan aktivitas metakognitif siswa, sehingga dapat memupuk sifat teliti, kritis, dan terampil dalam mengambil keputusan.

Dalam penelitian aktivitas metakognitif ini peneliti tidak melakukan intervensi berbentuk bantuan (scaffolding) pada saat subjek mengalami kesulitan atau kesalahan, sampai subjek sadar dengan sendirinya bahwa ia mengalami kesalahan. Hal ini menarik perhatian peneliti, sehingga dalam penelitian ini diperlukan waktu yang cukup lama sampai subjek dengan menemukan kesalahan dan memperbaikinya. Disarankan kepada guru yang menemukan kasus serupa untuk mengintervensi/memberikan sedikit bantuan (scaffolding) pada bagian dimana siswa mengalami kesulitan, dengan cara memberikan pertanyaan-pertanyaan yang mengarahkan dan membimbingkan siswa untuk memperbaiki kesalahannya. Dengan kata lain, diberikan stimulus pertanyaan untuk memeriksa kembali bagian yang menyulitkan siswa saja.

\section{DAFTAR PUSTAKA}

Bruning, R.H., Schraw, G.J., \& Ronning, R.R. (1995). Cognitive Psychology and Instruction, Second Edition. New Yersey. Prentice Hall.

De Corte, E. (2003). Intervention Research: a Tool for Bridging the Theory-Practice Gap in Mathematics Education. Proceedings of The International Conference, The Mathematics Education into the $21^{\text {st }}$ Century Project, Bernoceh Republic.

Depdiknas. (2006). Kurikulum Satuan Pendidikan (KTSP). Jakarta: Departemen Pendidikan Nasional.

Flavell, J.H. (1979). "Metacognition and Cognition Monitoring. A New area of Cognitive Developmental Inquiry". In Nelson, Thomas O.1992. Metacognition core Reading, 3-8: Allyn and Bacon, Boston.

Gartmann, S., \& Freiberg, M. (1995). Metacognition and mathematical problem solving: Helping students to ask the right questions. The Mathematics Educator, 6(1), 9-13.

Johnson, D.A. \& Rising, G.R. (1972). Guidelines forTeaching Mathematics. Boston, Wadsworth Publishing Company. 
142 Aria Joko Pramono, Aktivitas Metakognitif Siswa SMP dalam Pemecahan Masalah Matematika...

Lee, M. \& Baylor, A.L. (2006). "Designing Metacognitive Map For Web Based Learning". Educational Technology \& Society. (1), 344-348.

Mennum, D.S. \& Hart, L.C. (2012). "Elementary School Mathematics Teacher Traines' Metacognitiv Awareness Levels". Journal of International Education Research. Second quarter 2012. Volume 8 Number 2.

NCTM (The National Council of Teachers of Mathematics). (1980). Problem Solving in School Mathematics. INC 1906 Associantion Drive, Reston, Virginia 2209.

O’Neil, Jr. H.F. \& Brown, R.S. (1997). Differential Effects of Question Format in Math Assessment on Metacognition and $A f f e c t$. Los Angeles.
Polya, G. (1973). How to Solve It. A New Aspect of Mathematical Method. Princenton and Oxford: Princenton University Press.

Soedjadi, R. (2000). Kiat Pendidikan Matematika di Indonesia, Kontatasi Keadaan Masa Kini Menuju Harapan Masa Depan. Direktorat Jendral Pendidikan Tinggi Departemen Pendidikan Nasional: Jakarta.

Wadsworth, J.B. (1984). Piaget's Theory and Affective Development. Third Edition. New York \& London: Longman.

Woolfolk, A. (2009). Educational Psychology Active Learning Edition. Tenth Edition. Yogyakarta: Pustaka Pelajar. 